\title{
PEMT Gene
}

National Cancer Institute

\section{Source}

National Cancer Institute. PEMT Gene. NCI Thesaurus. Code C104965.

This gene plays a role in phosphatidylethanolamine metabolism. 